\title{
Sustainable Use of Fig Species Provides Nutrition and Medicine for Ethnic Minority Communities in the Southern Shan State of Myanmar
}

\author{
Aye Mya Mon \\ Kunming Institute of Botany Chinese Academy of Sciences \\ Yinxian Shi \\ Kunming Institute of Botany Chinese Academy of Sciences \\ Pyae Phyo Hein \\ Institute of Botany Chinese Academy of Sciences \\ Thaung Naing Oo \\ Forest Research Institute Forest Department \\ Cory W. Whitney ( $\sim$ cory.whitney@uni-bonn.de) \\ Institute of Botany Chinese Academy of Sciences \\ Xuefei Yang ( $\nabla$ xuefei@mail.kib.ac.cn )
}

\section{Research}

Keywords: Ficus, Ethnobotany, Traditional Knowledge, Food, Medicine, Conservation, Southern Shan State

Posted Date: May 20th, 2020

DOI: https://doi.org/10.21203/rs.3.rs-30301/v1

License: (c) This work is licensed under a Creative Commons Attribution 4.0 International License. Read Full License

Version of Record: A version of this preprint was published on September 17th, 2020. See the published version at https://doi.org/10.1186/s13002-020-00406-z. 


\section{Abstract}

Background: Fig trees are ecological keystone species in many tropical regions and play important roles in the spirituality, nutrition and health for many rural communities. Although the tropical forests in Myanmar contain many fig species, little ethnobotanical knowledge on their uses has been recorded.Information about the uses and conservation related actions of figswould be helpful in development of strategic policy for sustainable use and biodiversity conservation of the country. We showcase the rich ethnobotanical knowledge as well as the variety of collection and conservation practices related to figs among five ethnic groups in Southern Shan State.

Methods: We performed both key informant and semi-structured interviews with 114 informants from five ethnic groups. Their uses for figs were categorized according to local practices and recipes. Informants were asked about trends in conservation status over the past 10 years and any conservation related customs and practices. Data were analyzed quantitatively by use report (UR) and use value (UV).

Results: Informants reported the uses of eight fig species (Ficusauricularta F.concinna, F. geniculata F. hispida, F. racemosa, F. religiosa $F$. semicordata, and $F$. virens). F. geniculata and $F$. virens were most useful $(U R=228)$ and were used by all five ethnic groups, corresponding to a high use value (UV $=2)$. Treatments for 16 diseases were reported from seven species. Household consumption, economic, and sacred uses were accompanied by sustainable practices of harvest and protection. Traditional taboos, in situ and ex situ conservation were practiced especially for highly demanded species ( $F$. geniculata and F. virens), and the sacred fig F. religiosa.

Conclusion: Findings suggest that figs are useful for nutrition (all informants) and medicine (13.16\% of the informants) in the study area. Traditional taboos, in situ and ex situ conservation practices help to maintain sustainable utilization of locally important figs. This is an early contribution to the traditional knowledge of edible figs. Although similar uses have been reported in neighboring countries for seven of the fig species, the ethnobotanical use of $F$. concinna is novel.

\section{Background}

A large part of Myanmar is located within the Indo-Burma Biodiversity Hotspot, considered to be one of the most biologically important regions and most threatened reservoirs of flora and fauna on the planet [1]. Myanmar seeks to create a comprehensive framework for sustainable development to preserve natural ecosystems, which are considered to be essential to ensuring Myanmar's development goals for both present and future generations. The long-standing use of figs and traditional conservation practices may yield important knowledge to inform Myanmar's National Biodiversity Strategy and Action Plan (2015-2020) [2] and Sustainable Development Plans (2018-2030) [3]. Goal five of Myanmar's Sustainable Development Plan (2018-2030) focuses on the legal, institutional and policy frameworks to enforce protection and management of ecosystems and to strengthen conservation efforts. The plan also seeks to restore and safeguard ecosystems that provide essential services to ethnic and local communities, the poor and have other cultural values. Myanmar has a strong Buddhist culture with practices that include the conservation of figs. For example, the traditional watering festival to sacred fig tree is held on every full moon day of the Kasone month (the second month of the Myanmar lunar calendar, equivalent to the month of May in Gregorian calendar), in remembrance of the Buddha's enlightenment and the time he passed away to Nibbana under the sacred Bodhi tree 25 centuries earlier [4].

Figs (genus Ficus L.; family Moraceae) constitute one of the largest genera of angiosperms with more than 800 species [5] of moderate woody plants or trees, epiphytes and shrubs. They constitute an important part of the biodiversity in many tropical areas of the world including Indo-Australasia, Neotropical and Afrotropical regions [6]. Figs are used by humans for food, health and other functional and cultural purposes throughout their distribution region [7]. Notable species of the genus are the sacred fig (Ficus religiosa L.), sacred to Hindus and Buddhists and others throughout the world [8]; the sycamore fig 
or the fig-mulberry (Ficus sycomorus L.), also known as the "tree of life" in Egypt [7]; the Indian rubber tree (Ficus elastica Roxb. ex Hornem.), one of the few potential crops for producing natural rubber [9]; cluster fig (Ficus racemosa L.), considered sacred to the god Dattaguru in India [10]; banyan tree (Ficus benghalensis L.), sacred to Hindus and Buddhists; common fig (Ficus carica L.), the most popular species has been cultivated for food and medicine for over 11,000 years [11]; roxburgh fig (Ficus auriculata L.) and white fig (Ficus virens Aiton), which are the most commonly consumed species in tropical regions (mainly young leaves and leaf buds) [12].

There are currently 95 botanical records of fig species in Myanmar [13]. At least 20 of these species are considered important ingredients in traditional medicine $[14,15]$, among other uses. Traditional knowledge on fig use is often transmitted orally from generation to generation and is an integral part of many local people's cultural identity. Some uses are published in ancient medicinal encyclopedias compiled by monks who tend to be the holders and transmitters of traditional religious knowledge [15]. However, formal records and studies of the traditional uses of figs among Myanmar's diverse ethnic groups are limited and only a few formal medicinal or nutritional studies have been performed to describe the medicinal plants or verify known uses $[16,17]$. These traditional uses often have accompanying conservation practices that may offer clues to help to guide Myanmar in developing policy for sustainable development.

The field of ethnobotany can help in defining and strengthening the preservation of native biodiversity. The field offers opportunities for the collection and recording of traditional knowledge and the preservation of the relevant species [18]. Through the current study we aimed to investigate the ethnobotanical knowledge of figs as well as collection and conservation practices. We offer a case study of knowledge holders from five ethnic groups in the Southern Shan State of Myanmar. Our objective was to document the use and conservation of important figs. We sought to explain 1) the diversity of figs that are of cultural relevance in the study area (Southern Shan State), 2) differences in the diversity of uses and species among the local ethnic groups in four townships of study area, and 3) conservation practices on figs in the study area. The work contributes to the body of knowledge on sustainable use and conservation of figs to support the Myanmar government's strategic plan for biodiversity conservation [2]. The collection and publication of this knowledge offers recognition for ethnic minorities and indigenous peoples as experts and as owners of important traditional knowledge. It gives credit for their contributions to preservation of this knowledge and conservation of biodiversity in Myanmar.

\section{Methods}

\section{Study area and sample sites}

Shan State is located on the Shan plateau in the central eastern part of Myanmar $\left(19^{\circ} 17^{\prime} \mathrm{N}\right.$ and $24^{\circ} 13^{\prime} \mathrm{N}$ and $96^{\circ} 10^{\prime} \mathrm{E}$ and $101^{\circ} 11^{\prime} \mathrm{E}$ ). It covers $155,800 \mathrm{~km}^{2}$, accounting for almost a quarter (23.2\%) of the total area of Myanmar. The plateau has an average elevation of $900 \mathrm{~m}$ above sea level. Average annual precipitation is between $1900 \mathrm{~mm}$ and $2000 \mathrm{~mm}$ [19]. The weather is divided into three seasons. The winter season lasts from November to February, the summer season is from March to June and ends in a rainy season between July and October. Annual mean temperatures range from $12{ }^{\circ} \mathrm{C}$ to $25^{\circ} \mathrm{C}$ [20].

The state is named after the Shan people who make up half the population of the state. Shan State is divided into Northern Shan State, Southern Shan State, and Eastern Shan State [21], most areas are highly restricted to travel even for local residents and are out of the political control of the central government [22]. It is bordered by China to the north, Laos to the east, and Thailand to the south. The region is home to 33 of the 135 ethnic groups in Myanmar. It is the second most diverse ethnic area after Chin State [22]. The language and culture of the state is similar to that of the Thai neighbors to the east [22]. The state population is 5.8 million, most are Buddhist (81.7\%), followed by Christian (9.8\%), Animist (6.6\%), Muslim (1\%), Hindu (0.1\%), Atheist and others (>1\%) [23]. Local livelihoods are based on paddy rice cultivation in small lowland basins and shifting cultivation of vegetables on the surrounding hillsides [24]. These shifting cultivation practices are giving way to permanent cultivation of cash crops such as tea, orange and pear. Despite these changes, the wild harvest 
of subsistence resources from forests is still common and plays an important role in the daily lives of local people. Related local traditional knowledge about nature and plants is important to local people and has been passed down for many generations, largely as part of the local spiritual practices [22].

Southern Shan State is the most accessible of the regions of Shan State and hosts 15 of the 95 figs in the Myanmar plant checklist [13]. In order to explore the use of figs in this region we selected seven villages based on secondary information about the prevalence of fig use, and information from fig collectors and sellers at local markets. We conducted surveys in Pindaya Township, Nyaung Shwe Township, Hopong Township and Taunggyi Township. Pindaya Township is a Danu selfadministrative area and most of the local inhabitants belong to the Danu ethnic group [22]. The Danu villages cultivate tea on the hill sides as their main source of livelihood together with coffee, orange, avocado, cabbage and mustard crops. Inhabitants of the Nyaung Shwe Township are mainly from the Intha ethnic group, who occupy Inle Lake (second largest lake in Myanmar). The Intha people make their livelihoods by cultivating tomato and other minor crops on the masses of floating roots and soil, and operate fish farms. Hopong Township is in the $\mathrm{Pa}-\mathrm{O}$ self-administrative area, with $56 \% \mathrm{~Pa}-\mathrm{O}$ ethnic people [25]. The Pa-O people make their livelihoods by cultivating Thanatphet (Cordia myxa), rice, corn, potato, pigeon pea, turmeric and other garden crops. Some also collect figs for additional income. In Taunggyi Township, most of the informants we interviewed belong to the Shan and Bamar ethnic majority of Myanmar. They were engaged with selling vegetables together with figs in the township level vegetable markets. Informants were identified through snow-ball sampling [26], this was extremely useful for identifying local people with knowledge about figs, particularly healers and monks who could tell us about medicinal uses.

\section{Ethnobotanical Data Collection}

We selected the potential study sites during preliminary field surveys and visits to local vegetable markets in December, 2016. We conducted formal surveys with a total of 114 informants from January to February in 2018 and followed up with supplementary field surveys in December 2018 with groups of key informants. The supplementary field survey was conducted to confirm some unclear information and to collect additional voucher specimens for those species without complete information (for example; voucher specimens without fruit). The first meetings were organized with the village leaders, elders, monks and individual informants, and the objectives of the research were explained. Prior informed consent and approval were received before we started each interview. We conducted fieldwork at three main locations in each township:

In the market, we interviewed 32 sellers about popular and marketable figs at five markets in four townships.

In Buddhist monasteries, we interviewed six monks; three of them are medicinal experts, and one nun about traditional Buddhist medicinal uses in five monasteries. We also interviewed four members of women's groups and volunteer groups, serving general duties at monasteries.

In villagers' homes, farming plots and wild collection sites, we interviewed 70 informants, on the use of figs in seven villages. We also visited the homes of medicinal experts that were known to be particularly knowledgeable about medicinal plants.

At the beginning of each interview we asked informants whether they use any figs for dietary purpose. After discussing these we shared fresh specimens and photographs of those that are commonly used in the area according to the Myanmar plant checklist [13] and nearby areas with similar demographic conditions [12]. We followed ethnobotany theory and methods related to plant species uses [27, 28], related socio-economic and conservation practices [29]. To better understand uses, we asked open-ended questions about traditional modes of consumption, medicinal uses, local names and folk names, collection season and the status of the wild population. For the conservation status, we asked informants to tell us about the availability of the species in the present compared to the past 10 years and their current conservation status. Interviews were carried out in the Burmese language, common to all five ethnic groups, with the assistance of local guides 
with language translations. We identified folk names for each plant species and variety. All informants were requested to pronounce the folk names of each species of which we made a voice recording. When there were different pronunciations for one species in one ethnic group we confirmed it again with key informants. We used the descriptions and pronunciations to compare folk classification.

\section{Voucher Specimen Collection}

To ensure correct species identification, we collected three or more sets of voucher specimens for each species. Voucher specimens were collected in nearby forests through transect walks [30] with the informants and in the villagers' home compound if the plant was cultivated. Collection was performed as part of the interview to verify the species and to help in identifying other figs collected and consumed in the area but not necessarily sold in the market. Each voucher specimen was assigned a specific code and GPS location. Photos of fresh and dry specimens were recorded and verified with plant taxonomists; Dr. Wattana Tanming from Queen Sirikit Botanic Garden, Thailand, Dr. Gang Wang from Xishuangbanna Tropical Botanical Garden, and Mrs. Jun Yang from Kunming Institute of Botany, Chinese Academy of Sciences. Voucher specimens were deposited at the herbarium of Kunming Institute of Botany (KUN), China and the herbarium of Forest Research Institute (RAF), Myanmar. Accepted taxonomic names were verified with the "World Flora Online" database [31].

\section{Quantitative Assessment}

We followed quantitative ethnobotany approaches to allow for assessment of the qualitative data [27, 32]. Categorization is a critical step in quantitative ethnobotany. We generated four categories of fig uses into: 1 . food, 2 . acute disease, 3 . chronic disease, and 4. animal feed (Table 1). We also generated a set of sub-categories of uses for food into vegetable and fruits following a the process proposed by Bhatia et al. (2018) [33]. Vegetable uses were divided into five sub-categories of use for young leaves and leaf buds, and four sub-categories for ripe or unripe fruits following by the local uses and recipes. We also assessed every use report of health treatment into ten sub-categories for acute diseases and six sub-categories for chronic diseases. Animal feeding was also divided into two sub-categories. Conservation practices for the fig species were also counted (but not categorized).

Table 1

Categorization of fig uses for food, acute diseases, chronic diseases and animal feed

\begin{tabular}{|c|c|c|c|c|}
\hline \multicolumn{2}{|l|}{ Food } & \multirow[t]{2}{*}{ Acute diseases } & \multirow[t]{2}{*}{ Chronic diseases } & \multirow[t]{2}{*}{ Animal feed } \\
\hline Vegetable uses & Fruit uses & & & \\
\hline Cooked & Eaten raw & Snake bites & Heart disease & Feeding cattle \\
\hline Fried & Processed & Cuts and wounds & Urine disease & Feeding pig \\
\hline Eaten raw & Preserved & Diarrhoea & Diabetes & \\
\hline Salad & Beverage & Indigestion & Fever & \\
\hline \multirow[t]{6}{*}{ Preserved } & & Excessive sweating & Hypertension & \\
\hline & & Postpartum supplement & Pulmonary disease & \\
\hline & & Constipation & & \\
\hline & & Irregular mensuration & & \\
\hline & & Longevity & & \\
\hline & & Herpes & & \\
\hline
\end{tabular}

Page 5/19 
We used the Use Report (UR) calculation as the basis for quantitative assessments. A UR is counted when an informant reports the use of a species within a specified use category [34]. For example, roxburgh fig was used as a cooked vegetable by two informants, raw fruit by four informants and as a heart disease treatment by one informant, giving it a total UR of 7 .

We used the Use Value index (UV), to demonstrate the relative importance of a species using the formula $U V=U / N$, where $U$ is the number of citations per species and $\mathrm{N}$ is the number of informants [34]. High UV for a plant implies that the plant is useful and a low score indicates that the plant is of negligible importance.

All analyses were performed in R programming language [35] using the ethnobotanyR package [36]. The inter-relationships of general categories between data in resulting matrices are displayed using chord diagrams generated with ethnobotany $\mathrm{R}$ package. Data on uses for food and medicine and related conservation practices were summarized into an alluvial diagram using the ggalluvial package [37].

\section{Results}

Nearly all informants $(99.12 \%)$ were native to the place where they were interviewed. The ages of informants varied from 15 to 80 years (Table 1). Out of five ethnic groups, Pa-O represented over half of all informants (they did the most collecting and warranted a heavier research effort) whereas Bamar represented the fewest respondents (mainly market stall managers) (Table 1). In this study, informants mentioned a total of eight species. The species names and voucher specimen numbers for each species are shown in (Table 2).

Table 2

Demographic information of the 114 informants from five ethnic groups in Southern Shan State, Myanmar

\begin{tabular}{|c|c|c|c|c|c|c|c|c|c|c|c|}
\hline \multirow[t]{2}{*}{ Role } & \multicolumn{5}{|c|}{ Ethnic belonging } & \multicolumn{2}{|l|}{ Gender } & \multicolumn{3}{|l|}{ Age } & \multirow[t]{2}{*}{ Total } \\
\hline & Danu & Intha & $\begin{array}{l}\mathrm{Pa}- \\
0\end{array}$ & Shan & Bamar & Female & Male & $\begin{array}{l}15- \\
40\end{array}$ & $\begin{array}{l}41- \\
65\end{array}$ & $\begin{array}{l}66- \\
90\end{array}$ & \\
\hline Vegetable seller & 1 & 4 & 19 & 4 & 4 & 29 & 3 & 18 & 13 & 1 & 32 \\
\hline $\begin{array}{l}\text { Religious person } \\
\text { and healer }\end{array}$ & 2 & 2 & 4 & - & - & 1 & 7 & 1 & 4 & 3 & 8 \\
\hline $\begin{array}{l}\text { Informed } \\
\text { consumer (Farm } \\
\text { cultivater) }\end{array}$ & 22 & 1 & 31 & 1 & - & 28 & 27 & 24 & 25 & 6 & 57 \\
\hline $\begin{array}{l}\text { Informed } \\
\text { consumer (Others) }\end{array}$ & 1 & 4 & 7 & 3 & - & 9 & 6 & 11 & 4 & - & 17 \\
\hline
\end{tabular}

\section{Folk And Taxonomic Names}

Local naming systems distinguish figs according to shape, size and taste of leaves and fruit (Table 3). Although no common name exists for all the species in the genus, most of the big Bayan trees and related species in the genus Ficus start with the local prefix "Nyaung" in Burmese languages. For example, F. concinna is "Nyaung-thabye", F. geniculata, and white fig are called "Nyaung-chin", and the sacred fig is "Nyaung-bodhi" or "Nyaung-taw". Sometimes, local people name the plants based on the flavor of the edible parts. For example, sour tastes are "chin" in Burmese languages, so a sour young fig leaf bud is called "Nyaung-chin-phoo". For this reason, F. geniculata, and white fig share the same name "Nyaung-chin". In Shan language, F. geniculata and white fig are described as "Phak-hee" meaning 'the wild vegetable with sour taste'. In the $\mathrm{Pa}-\mathrm{O}$ language, the word "cha" means edible; the edible female fig of $F$. semicordata is called "Thadut-cha", the edible $F$. geniculata and White fig share the name "Kharone-cha". 
Table 3

Details regarding eight fig species and their usefulness as food, medicine and any related conservation practices for 114 informants from five ethnic groups in Southern Shan State, Myanmar

\begin{tabular}{|c|c|c|c|c|c|c|c|c|c|}
\hline \multirow{2}{*}{$\begin{array}{l}\text { Botanical } \\
\text { name }\end{array}$} & \multirow{2}{*}{$\begin{array}{l}\text { Growth } \\
\text { Habit }\end{array}$} & \multirow{2}{*}{$\begin{array}{l}\text { Primary } \\
\text { harvest } \\
\text { period }\end{array}$} & \multirow{2}{*}{$\begin{array}{l}\text { Edible } \\
\text { parts }\end{array}$} & \multicolumn{5}{|c|}{ Vernacular names } & \multirow{2}{*}{$\begin{array}{l}\text { Voucher } \\
\text { number }\end{array}$} \\
\hline & & & & $\begin{array}{l}\text { Burmese } \\
\text { (English } \\
\text { translation) }\end{array}$ & Danu & Intha & $\mathrm{Pa}-\mathrm{O}$ & Shan & \\
\hline \multirow[t]{3}{*}{$\begin{array}{l}\text { F. auriculata } \\
\text { Lour. }\end{array}$} & $\begin{array}{l}\text { Small } \\
\text { tree }\end{array}$ & $\begin{array}{l}\text { February- } \\
\text { March }\end{array}$ & $\begin{array}{l}\text { Young } \\
\text { leaves }\end{array}$ & \multirow{3}{*}{$\begin{array}{l}\text { Sin-tha- } \\
\text { phan } \\
\text { (elephant } \\
\text { fig) }\end{array}$} & \multirow{3}{*}{$\begin{array}{l}\text { Phak- } \\
\text { ohn/ } \\
\text { Phak- } \\
\text { wah }\end{array}$} & \multirow{3}{*}{$\begin{array}{l}\text { Phak- } \\
\text { ohn/ } \\
\text { Phak- } \\
\text { wah }\end{array}$} & \multirow{3}{*}{$\begin{array}{l}\text { Phak- } \\
\text { ohn/ } \\
\text { Phak- } \\
\text { wah }\end{array}$} & \multirow{3}{*}{$\begin{array}{l}\text { Phak- } \\
\text { ohn/ } \\
\text { Phak- } \\
\text { wah }\end{array}$} & $\begin{array}{l}\text { EBF } \\
1804\end{array}$ \\
\hline & $\begin{array}{l}(5- \\
10 \mathrm{~m})\end{array}$ & $\begin{array}{l}\text { October- } \\
\text { December }\end{array}$ & $\begin{array}{l}\text { Ripe } \\
\text { female }\end{array}$ & & & & & & $\begin{array}{l}\text { EBF } \\
1813\end{array}$ \\
\hline & & August & $\begin{array}{l}\text { young } \\
\text { green } \\
\text { fig }\end{array}$ & & & & & & $\begin{array}{l}\text { EBF } \\
1807\end{array}$ \\
\hline \multirow{2}{*}{$\begin{array}{l}\text { F. concinna } \\
\text { (Miq.) Miq. }\end{array}$} & Tree & \multirow{2}{*}{$\begin{array}{l}\text { February- } \\
\text { April }\end{array}$} & \multirow{2}{*}{$\begin{array}{l}\text { Young } \\
\text { leaves }\end{array}$} & \multirow{2}{*}{$\begin{array}{l}\text { Nyaung- } \\
\text { thabye, } \\
\text { Nyaung- } \\
\text { pan }\end{array}$} & Nyaung- & \multirow[t]{2}{*}{-} & \multirow[t]{2}{*}{-} & \multirow{2}{*}{$\begin{array}{l}\text { Mike- } \\
\text { nyaung }\end{array}$} & \multirow{2}{*}{$\begin{array}{l}\text { EBF } \\
1805\end{array}$} \\
\hline & $\begin{array}{l}(< \\
10 \mathrm{~m})\end{array}$ & & & & Thabye & & & & \\
\hline \multirow{2}{*}{$\begin{array}{l}\text { F. } \\
\text { geniculata } \\
\text { Kurz }\end{array}$} & $\begin{array}{l}\text { Large } \\
\text { tree }\end{array}$ & \multirow[t]{2}{*}{$\begin{array}{l}\text { February- } \\
\text { March }\end{array}$} & \multirow{2}{*}{$\begin{array}{l}\text { Young } \\
\text { leaf } \\
\text { buds }\end{array}$} & \multirow[t]{2}{*}{$\begin{array}{l}\text { Nyaung- } \\
\text { chin }\end{array}$} & \multirow[t]{2}{*}{$\begin{array}{l}\text { Nyaung- } \\
\text { chin }\end{array}$} & \multirow[t]{2}{*}{$\begin{array}{l}\text { Nyaung- } \\
\text { chin }\end{array}$} & \multirow[t]{2}{*}{ Kharone } & \multirow[t]{2}{*}{$\begin{array}{l}\text { Phak- } \\
\text { hee }\end{array}$} & $\begin{array}{l}\text { EBF } \\
1815\end{array}$ \\
\hline & $\begin{array}{l}(< \\
20 \mathrm{~m})\end{array}$ & & & & & & & & $\begin{array}{l}\text { EBF } \\
1812\end{array}$ \\
\hline \multirow[t]{3}{*}{$\begin{array}{l}\text { F. hispida } \\
\text { L.f. }\end{array}$} & \multirow{3}{*}{$\begin{array}{l}\text { Small } \\
\text { tree } \\
(5- \\
10 \mathrm{~m})\end{array}$} & $\begin{array}{l}\text { March- } \\
\text { April, }\end{array}$ & $\begin{array}{l}\text { Young } \\
\text { leaves }\end{array}$ & \multirow[t]{3}{*}{$\begin{array}{l}\text { Kha-aung, } \\
\text { Pha-aung }\end{array}$} & \multirow[t]{3}{*}{$\begin{array}{l}\text { Kha- } \\
\text { aung }\end{array}$} & & & & \multirow[t]{3}{*}{$\begin{array}{l}\text { EBF } \\
1809\end{array}$} \\
\hline & & $\begin{array}{l}\text { the whole } \\
\text { year }\end{array}$ & & & & & & & \\
\hline & & $\begin{array}{l}\text { The whole } \\
\text { year, } \\
\text { October- } \\
\text { November }\end{array}$ & $\begin{array}{l}\text { Ripe } \\
\text { fig and } \\
\text { young } \\
\text { green } \\
\text { fig }\end{array}$ & & & & & & \\
\hline \multirow[t]{2}{*}{$\begin{array}{l}\text { F. racemosa } \\
\text { L. }\end{array}$} & $\begin{array}{l}\text { Large } \\
\text { tree }\end{array}$ & $\begin{array}{l}\text { February- } \\
\text { March }\end{array}$ & $\begin{array}{l}\text { Young } \\
\text { leaves }\end{array}$ & \multirow[t]{2}{*}{ Tha-phan } & $\begin{array}{l}\text { Tha- } \\
\text { phan }\end{array}$ & $\begin{array}{l}\text { Tha- } \\
\text { phan }\end{array}$ & Phak-de & $\begin{array}{l}\text { Mike- } \\
\text { lay/ }\end{array}$ & $\begin{array}{l}\text { EBE } \\
1810\end{array}$ \\
\hline & $\begin{array}{l}(< \\
20 \mathrm{~m})\end{array}$ & $\begin{array}{l}\text { October- } \\
\text { December } \\
\text { and July- } \\
\text { August }\end{array}$ & $\begin{array}{l}\text { Ripe } \\
\text { fig and } \\
\text { young } \\
\text { green } \\
\text { fig }\end{array}$ & & & & & $\begin{array}{l}\text { Phak- } \\
\text { lay }\end{array}$ & $\begin{array}{l}\text { EBF } \\
1811\end{array}$ \\
\hline $\begin{array}{l}\text { F. religiosa } \\
\text { L. }\end{array}$ & $\begin{array}{l}\text { Tree } \\
(15- \\
30 \mathrm{~m})\end{array}$ & $\begin{array}{l}\text { February- } \\
\text { March }\end{array}$ & $\begin{array}{l}\text { Young } \\
\text { leaves }\end{array}$ & $\begin{array}{l}\text { Nyaung- } \\
\text { bawdi } \\
\text { (sacred fig) }\end{array}$ & $\begin{array}{l}\text { Nyaung- } \\
\text { taw }\end{array}$ & $\begin{array}{l}\text { Nyaung- } \\
\text { ni }\end{array}$ & $\begin{array}{l}\text { Nyaung- } \\
\text { ni }\end{array}$ & $\begin{array}{l}\text { Phak- } \\
\text { nyaung }\end{array}$ & $\begin{array}{l}\text { EBF } \\
1803\end{array}$ \\
\hline $\begin{array}{l}\text { F. } \\
\text { semicordata } \\
\text { Buch.-Ham. } \\
\text { ex Sm. }\end{array}$ & $\begin{array}{l}\text { Tree } \\
(< \\
10 \mathrm{~m})\end{array}$ & $\begin{array}{l}\text { October- } \\
\text { December, } \\
\text { June- } \\
\text { August }\end{array}$ & $\begin{array}{l}\text { Ripe } \\
\text { female } \\
\text { figs }\end{array}$ & Kadut & Kadut & Thadut & Thadut & Thadut & $\begin{array}{l}\text { EBF } \\
1802\end{array}$ \\
\hline $\begin{array}{l}\text { F. virens } \\
\text { Aiton }\end{array}$ & $\begin{array}{l}\text { Large } \\
\text { tree }\end{array}$ & $\begin{array}{l}\text { February- } \\
\text { March }\end{array}$ & $\begin{array}{l}\text { Young } \\
\text { leaf } \\
\text { buds }\end{array}$ & $\begin{array}{l}\text { Nyaung- } \\
\text { chin }\end{array}$ & $\begin{array}{l}\text { Nyaung- } \\
\text { chin }\end{array}$ & $\begin{array}{l}\text { Nyaung- } \\
\text { chin }\end{array}$ & Kharone & $\begin{array}{l}\text { Phak- } \\
\text { hee }\end{array}$ & $\begin{array}{l}\text { EBF } \\
1801\end{array}$ \\
\hline & $\begin{array}{l}(< \\
20 \mathrm{~m})\end{array}$ & & & & & & & & $\begin{array}{l}\text { EBF } \\
1808\end{array}$ \\
\hline
\end{tabular}


The Burmese name for roxburgh fig is "Sin-thaphan", which means "Elephant fig" due to its large leaf. Danu, Shan, Intha, and $\mathrm{Pa}-\mathrm{O}$ share the name "Phak-ohn" or "Phak-wah" for this species, meaning "big leaf fig tree", similar to the meaning of "elephant fig" in Burmese language. F. racemosa shares the same ethnic name "Phak-de" for the Pa-O and Danu. Intha and Shan call it "Tha-phan".

F. regligiosa is considered a sacred tree across the study region. The Bamar call it "Nyaung-bodhi" meaning "Buddha tree". The Danu people call it "Nyaung-taw", with the respectful "taw" for worshiping Buddha and elders in the Buddhist community. The Intha and Pa-O call it "Nyaung-ni" referring to the red colored young leaves. The Shan show their respect for the sacred fig with the name "Phak-nyaung" (Table 2) with "Phak" for wild vegetable and the respectful affix "nyaung".

F. geniculata and white fig are considered to be distinct species but were given the same local name and local people could not differentiate between them. F. oligodon and F. hainanensis were considered to be the same ethnospecies as roxburgh fig across local communities and are also described as synonyms for roxburgh fig according to the "World Flora Online" database [31]

\section{Use Value}

There were altogether 923 use-reports in all four use categories (Fig. 2). The greatest number of use-reports $(U R=228)$ were recorded for $F$. geniculata and white fig and each of these species had a correspondingly high use value (UV $=2)$. These two important species were followed by cluster fig with (UR = 144, UV =1.26), F. semicordata $(U R=114, U V=1)$, roxburgh fig (UR $=108, \mathrm{UV}=0.95)$, the sacred fig $(\mathrm{UR}=54, \mathrm{UV}=0.47), F$. hispida $(\mathrm{UR}=29, \mathrm{UV}=0.25)$, and $F$. concinna $(\mathrm{UR}=18, \mathrm{UV}=0.16)$.

\section{General Used Categories}

The generalized use categories of figs are shown in Fig. 2. All the eight fig species were mainly used for food followed by acute disease, chronic disease and animal feed. F. concinna was only reported for food. While F. religiosa was reported for food and acute disease uses, F. geniculata and F. virens were reported for food, acute and chronic disease uses, and the rest of the species were reported for all four use categories.

\section{Food Uses}

Most of the uses reported were for food (sum UR food= 865) in all four townships (Fig. 3). The young green figs of roxburgh fig, cluster fig, F. hispida and F. semicordata were commonly eaten as salad or as a side dish with fish paste and preserved in salt water. The ripe figs of these species are also eaten directly or with jaggery and sugar as a snack. A homemade beverage is made from the ripe figs of $F$. semicordata by preserving them with sugar for one or more weeks. Only the ripe female figs of dioecious figs are edible, the male fruits are low in nutrients and not palatable [12]. A proverb among Intha people compares the male fruit of dioecious fig with insincere people 'although they may look good, there are wasps inside and the taste is poor'. The young leaves or leaf buds of all the reported figs except $F$. semicordata were eaten as vegetables in salad, soup, or fried with rice powder.

Young leaves and leaf buds were the most common edible parts when compared with fruit. They were most commonly prepared in soup with peas and beans or in potato soup by all five ethnic groups. The Intha "Say-khar" soup is mainly made of cluster fig leaves. Young boiled fig leaves are often paired with tomato sauce or fish paste as a side dish. The mixture of young leaves and rice powder are fried and eaten as a vegetable pakora. The young leaves or leaf buds are also preserved with salt in bamboo tubes to be eaten year-round. The pickled young leaves are used in salads and side dishes or as a snack with evening tea. The fruits of F. concinnna, F. geniculata, white fig and leaves of F. semicordata were not reported to be eaten. 


\section{Feeding Animals}

Fig fruits were used as animal feed and fodder by five informants of Pa-O people and one Danu informant (sum UR animal feed $=9$ ). The ripe fig of roxburgh fig was used to feed pigs and F. hispida, cluster fig tree and F. semicordata were used to feed both pigs and cattle. Fig leaves were not reported to be used for feed.

\section{Medicinal Uses}

Except $F$. concinna all species are used for medicine across the four townships. They are used for treating 16 major health conditions (sum UR medicinal uses $=46$ ). The leaves, fruits and latex are used to treat topical and internal diseases including: snake bites (9 UR), the white latex of F. hispida, cluster fig and F. semicordata are applied topically; heart disease ( 6 UR), the ripe fruits of roxburgh fig, cluster fig, and $F$. semicordata are eaten directly or in jam mixed with jaggery or sugar; cuts and wounds (6 UR), young leaves of F. geniculata, white fig, cluster fig and the sacred fig are eaten raw or cooked, the white latex of the sacred fig is applied directly, the crushed fruit of $F$. hispida is used as a plaster; urinary diseases (5 UR), the ripe fruit of $F$. semicordata is eaten directly, leaves from F. geniculata and white fig are eaten as a soup. This soup is also used for treating diarrhea (3 UR), indigestion (3 UR), excessive sweating (2 UR) and as a tonic for postpartum health (2 UR). Other medical treatments include diabetes (3 UR), young leaves of F. geniculata, F. hispida, and white fig are eaten as side dish after boiling in hot water; constipation (1 UR), ripe fruit of $F$. semicordata eaten directly; fever (1 UR), ripe fig of cluster fig is roasted over fire and taken with salt; hypertension (1 UR), young leaves of $F$. hispida are eaten as side dish after boiling in hot water; irregular mensuration (1 UR), ripe fruit of $F$. semicordata eaten directly or in jam mixed with jaggery or sugar; longevity (1 UR), ripe fruit of $F$. semicordata is preserved with honey or sugar and taken year-round for longevity of elderly patients and those in menopause; herpes (1 UR), latex of cluster fig is applied on the skin; and pulmonary diseases (i.e. asthma and other overabundance of mucus) (1 UR), the ripe fruit of $F$. semicordata is eaten directly. The medicinal uses of all fig species are shown in Fig. 3.

\section{Economic Uses}

Economic uses were common (sum UR economic uses $=88$ ). The mature leaves of $F$. semicordata were reported to be used for polishing wood by one Danu informant. The young leaves and buds of $F$. geniculata, cluster fig and white fig were sold as vegetable in local markets in all four townships. Many of these were found in Hopong market and were reported to be in high demand during their short available season. F. geniculata and white fig were sold as one species based on the sizes of leaves and buds. It was estimated that fig sales generate up to $10 \%$ of household incomes for fig wild collectors, and up to $5 \%$ of household incomes of vendors (vegetable sellers). This income comes primarily during the intensive collection period.

\section{Conservation Status}

In general fig species are well managed and conserved mainly under the influence of religion belief. Conservation practices were reported for all fig species. Informants in all the cultural groups in four townships except Bamarstated that all the species are conserved in the wild as a part of wild collection, especially species in high demand such as $F$. genicula and $F$. virens(111 out of 114 informants reported to use). They retain and protect the wild edible figs growing around the villages and farms for seasonal food, shading and fencing. 36 (32\%) informants were reported that they cultivate fig trees in their home compounds for household consumption and sometime sell the surplus.

Depending on the size, age and location of the individual tree, local people believe that they are home to tree-gods. They customarily preserve the tree from the religious point of view and disturbing or damaging the tree is taboo. Many of the communities worship a tree-god (the guardian spirit of tree) called Yokka-soe who is guarding the sacred fig tree ( $F$. religiosa), bayan trees( $F$. benghalensis L.), as well as long-lived big trees. People believed that the tree-god (Yokka-soe) is 
benevolent to humans. On the other hand, he may harm to human if someone misbehave to him or the tree he is guarding. $15(13 \%)$ informants reported that they have their own experience with that when they tried to collect some of the fig trees. While 94 (82\%) informants said that they have ever heard about taboo from the older generations and the other people who have experience of breaking the taboo. There are five fig species; $F$. religiosa(10 citations), F. racemosa (3 citations), $F$. geniculata (1 citation), F. concinna (1 citation), and F. virens (1 citation) reported to conserveunder traditional taboo because of their size, age and location in this study.

However, there are some actions of local people influencing negative impact on the sustainable use of figs. Firewood collection and small-scale charcoal burning (only reported in Pindaya Township) have minor negative impacts. Local people collect firewood for drying tea leaves. F. semicordata is the most cited species for firewood (UR Firewood = 78). Some other minor risks are over-collection of young leaves and leaf buds for both household consumption and selling. Farmland extensions and road extensions are also threats.

When asked to assess changes in the availability of figs in the past 10 years $73 \%$ of the informants said there were no obvious changes. 94 out of 114 informants cited local conservation practices that inform and enforce sustainable collection. The importance of conservation practices across eight species in four townships was summarized based on the citation of 114 informants (Fig. 3).

\section{Harvesting Practice Of Fig By Local Ethnic Groups}

Informants responded that all the eight figs were harvested from the wild. F. geniculata and $F$. virens were commonly harvested followed by cluster fig, F. semicordata and F. concinna, roxburgh fig, and F. hispida. According to the informants, the best season for harvesting leaves and buds is in the late winter to summer and the best time to collect fruits is in the monsoon season. The production of young leaves and leaf buds is supported through pruning. Household consumption is the main purpose for collection but some surpluses are sold as a source of side income. The local people mentioned that fruits were mainly collected by the children as snack but they were not often eaten by adults and are left to grow wild. However, figs that are a source of fruit (e.g. roxburgh fig, F. hispida, and F. semicordata) are harvested twice annually, during peak fruit production from June to August and from October to December but can be collected in lower abundance throughout the year. The informants reported that the harvest times can vary according to weather and geographic conditions.

\section{Comparative Uses Among Ethnic Groups}

The number of species used was different among ethnic groups and geographic locations (Fig. 4). Danu and Pa-O had the greatest number of uses followed Shan, Intha and Bamar. The Danu and $\mathrm{Pa}-\mathrm{O}$ shared uses for eight figs. Danu, $\mathrm{Pa}-\mathrm{O}$ and Shan share uses for six species (roxburgh fig, F. geniculata, cluster fig, the sacred fig, F. semicordata, and white fig.). The Intha ethnic group shares five species with Danu, Shan and Pa-O (F. geniculata, cluster fig, the sacred fig, white fig and $F$. semicordata). The Bumar are the smallest informant group $(n=4)$ and only reported two figs (F. geniculata and white fig), which were also common to all other ethnic groups in the study area.

\section{Discussion}

\section{Fig species identification}

For those eight fig species, our approach of species identification using photos and samples was an effective tool. Based on these, informants were also able to indicate additional characteristics related to fruit, latex, young leaves or leaf buds, leaf sheath and stipules not shown in the photos and specimens. This helped us with identifying materials in the market. In the 
case of $F$. geniculata and white fig, they were considered to be the same ethnospecies but are different species according to botanical taxonomic identification. Similar approaches may be useful for other studies to differentiate between different species.

\section{Folk Names And Species Confirmation}

Gathering local names and learning about naming conventions was also useful to define monophyletic group of fig species. Roxburgh fig, F. oligodon and F. hainanensis were also the same ethnospecies among Danu, Pa-O and Shan. Molecular phylogeny research studies have revealed the same three forms as a [38] and the three were once considered synonyms of roxburgh fig [31]. It may be worthwhile to study more of the similarities among local names and molecular phylogeny. In this case, using molecular analyses such as sequence analysis of highly conserved genes and inter-genic spacers of chloroplast DNA could provide a clearer picture of differentiation between species.

\section{Food Uses Of Fig Species Compared To Other Studies}

The use of fresh fruits of cluster fig and F. semicordata were also reported elsewhere in Southern Shan State [17]. The frequent use of $F$. auriculata, F. racemosa and F. virens among others, is also similar in neighboring countries such as Vietnam, India, China, Nepal and Thailand [12, 39-41]. The young shoots and young leaves of $F$. geniculata and $F$. virens are also considered edible in Thailand [40]. According to $[42,43]$ the fruits of $F$. hispida are poisonous and can cause intestinal irritation which may lead to death when eaten. However, the ficin (the proteolytic enzyme included in the latex) is an effective to cure for intestinal worms' such as round-worms and hook-worms [44]. Interestingly, no informant in our study, not even local healers, reported that the fruit is harmful. Similar findings on edible leaf shoots and fruits of $F$. hispida has been reported in Malaysia [45]. Although no toxicity information was reported in the current study, this species should be studied further to determine the efficacy and safety evaluation for consumption.

\section{Feeding Animal}

Another interesting finding from our study was that only the fruits of four figs; roxburgh fig, F.hispida, cluster fig and $F$. semicordata were used as animal feed. Figs are commonly used as animal fodder in the Himalaya region and India especially for roxburgh fig [46-48]. The difference may be due to the year-round availability of fruits compared with young leaves, which can be collected only during a short season.

\section{Medicinal Important}

Monks are locally considered to be the source of wisdom [49]. They remain a primary source of health care. In matters of health all the ethnic groups except a few Bamar in this study rely on traditional plant medicines and consult local practitioners to cure their ailments. In the study area, seven out of eight edible figs had some medicinal use. In some cases, diet and medicine are difficult to distinguish [50], i.e. when preparing the leaves for healing soup or eating the ripe fruit specifically for medicinal benefits. Other medicinal uses were more obvious and easier to assess, i.e. topical treatments of latex and crushed fruit. Other studies have cited similar medicinal uses for these figs. In Nepal the tender shoots and fruits of roxburgh fig are used to treat diarrhea and dysentery [51], the ripe fruit of $F$. semicordata is eaten to treat constipation, indigestion [51, 52] and the white latex is used to treat boils [52]. In Pakistan, white fig leaves are used to treat diabetes and a decoction of the ripe fruit is used for the same purpose [53]. In north Pakistan, the powder from unripe fruits of cluster fig are eaten for intestinal worms, piles and menstrual disorders [54]. In Nepal the white latex of the same tree is used to treat muscular pain, cut wounds, fractures and boils and the infusion of $F$. hispida's bark is used to treat diabetes [53]. In India, the leaf juice of sacred fig is consumed to treat asthma, cough, diarrhea and gastric problems [8]. Medicinal figs should be 
further studied for their role in local health care, especially for those rural communities with limited access to conventional medicine.

\section{Socio-economic Important}

Our findings indicate that figs were also of socio-economic importance for rural people. We found diverse markets with some figs such as F. racemosa, F. geniculata, and F. virens sold as vegetables. This is consistent with other studies on the marketable importance of figs for food. Young fruit and leaves of $F$. auriculata, the young leaves of $F$. oligodon, and the leaf buds of $F$. virens are also sold on the local markets of Yunnan, China [12], the near-ripe peeled or unpeeled fruits and young leaves of $F$. auriculata were sold in the markets of north and central Vietnam [39], and the fruits of $F$. auriculata were sold in the cities in north Karnataka [55]. Moreover, the mature leaves of $F$. semicordata were used for polishing wood in India [56]. Over exploitation of marketable species from the wild may threaten the future availability. If demand grows there may be a need for wide-spread promotion and awareness-raising of traditional sustainable wild collection practices.

\section{Conservation status}

The availability of wild plant resources for both subsistence and markets depends upon sustainable harvests, appropriate management and the domestication of wild resources [57]. In this study, we observed cultural and indigenous knowledge related conservation practices for figs, passed down across generations. The villages in all the cultural groups in four townships except Bamartake action toward in situconservation practices, as well as domestication of edible figs. Promotion of these local customs related to sacred fig may result in better conservation strategies. The taboo keeping people from cutting fig trees is strong since many believe that it can be harmful to break taboo [58]. Based on this custom, the sacred figs are protected from cutting or overharvesting under the supervision of monks, especially those trees that are grown in the monastery compound. The culture of conserving figsfor sacred and religious purposes is common not only in Myanmar but also in other parts of the world [7]. Even though fig trees are reported to use for firewood, local people mentioned that figs are not really a good choice for firewood but can be used after making sundry to dry the latex if they have no other choice. The other minor risks of over collection and farmland extension areneglectable when compared with the positive practice of in situ and ex situ conservation. In situ conservation management can help to maintain natural populations of fig species in their natural habitats. The success of such management practices depends on rules, regulations, and compliance [59].Related interventions cansupport the conservation of figs. For example, a grant from the Rufford Small Grants Foundation from the UK promoted cultivation and conservation of two figs; 1) F. virens and 2) Ficusaltissima with the participation of local nature conservation committee, regional women's and welfare associations and volunteers in 116 villages of Pindaya Township in 2008 [60]. They introduced awareness-raising on the importance and the ecological role of fig trees to the relevance local groups including school children. More of such awareness-raising initiatives for sustainable utilization of figs should be performed with local communities in cooperation with national and international organizations to promote traditional knowledge on the sustainable use of natural resources. Further studies on the potential for expansion of existing traditional conservation practices may be part of the solution for maintaining the forest ecosystems of Myanmar.

\section{Conclusions}

Our study illustrates the importance of figs for local diets, medicine, supporting side incomes and feeding domestic animals across ethnic groups in Myanmar. The local ethnobotanical knowledge on the use of these figs has been transmitted orally and handed down through many generations of citizens, whereas medicinal knowledge is the realm of monks and healers. Moreover, traditional local customs and taboos regarding in situ and ex situ conservation practices was important for sustainable utilization in the area. Harvesting and other extractive uses such as collecting firewood are unlikely to have a negative effect on figs. However, extension of farmlands and roadways may put serious pressure on availability of figs species in the future. The conservation of figs and the preservation of traditional practices should be part of local 
conservation efforts by local and international organizations. In line with these efforts, more exploration and documentation of ethnobotany knowledge of the ethnic minority groups should be conducted. Further studies should also address the nutrient constituent and antioxidant activity of the edible figs explored in this study and throughout the country. The ethnic groups should be acknowledged as owners of the documented traditional knowledge, valuable to the identity of future generations. The benefits that may arise from the research should seek to contribute the preservation of the flora of Myanmar and support the sustainable development goals of Myanmar.

\section{Declarations}

\section{Ethics approval and consent to participate}

Ethics approval was granted by Kunming Institute of Botany (KIB), Chinese Academy of Sciences (CAS), China and Forest Research Institute (FRI), Ministry of Environmental Conservation and Forestry (MOECAF), Myanmar. Consent was obtained from the participants prior to this study being carried out. Permission to do the study wasgranted by all participants and relevant local leaders in the Shan, $\mathrm{Pa}-\mathrm{O}, \mathrm{Danu}$, Intha and Bamarcommunities.

\section{Consent for publication}

Not applicable.

\section{Availability of data and materials}

The datasets used andanalyzed during the current study are available from the corresponding author on reasonable request.

\section{Competing interests}

The authors declare that they have no competing interests.

\section{Funding}

This study was supported by the Southeast Asia Biodiversity Research Institute, Chinese Academy of Sciences (no. 2015CASEABRIRG001), the National Natural Science Foundation of China (no. 31670338, 31400286), and National Science \& Technology Fundamental Resources Investigation Program of China (2018FY100700).

\section{Authors' contributions}

AMM and PPH conducted field interviews, data, voucher specimen and other support materials collection. TNO provided technical guidance and support for conducting field survey in Myanmar. AMM and YS analyzed the data, designed and drafted the manuscript. XY and CWW gave instruction to the study design and revised the manuscript critically and shaped the final version. All authors read and approved the final manuscript.

\section{Acknowledgements}

We are grateful to Shan, Pa-O, Danu, Intha and Bamar people in the Southern Shan State of Myanmar for their assistance in the field investigations and for sharing their valuable knowledge. We would like to thank local experts from Taunggyi University for their valuable suggestions in selecting representative study sites. We owe special thanks to Dr. 
WattanaTanming from Queen Sirikit Botanic Garden, Thailand, Dr. Gang Wang from Xishuangbanna Tropical Botanical Garden, and Mrs. JunYang, Kunming Institute of Botany, Chinese Academy of Sciences for their support with the identification of the fig species.

\section{References}

1. Ingelmo IA. Design and Development of a Sustainable Tourism Indicator based on Human Activities Analysis in Inle Lake, Myanmar. Procedia - Soc Behav Sci Elsevier. 2013;103:262-72. http://doi.org/10.1016/J.SBSPRO.2013.10.334.

2. Forest D. National Biodiversity Strategy and Action Plan (2015-2020). 2015.

3. Ministry of P. and F. Myanmar Sustainable Development Plan (2018-2030). 2018.

4. Khin Myo Chit. Colorful Myanmar Tetlan Sarpay. 1995;3:275-6.

5. Singh D, Singh B, Goel RK. Traditional uses, phytochemistry and pharmacology of Ficus religiosa: A review. J Ethnopharmacol. 2011;134:565-83. http://dx.doi.org/10.1016/j.jep.2011.01.046.

6. Van Noort S, Gardiner AJ, Tolley KA. New records of Ficus (Moraceae) species emphasize the conservation significance of inselbergs in Mozambique. South African J Bot. 2007;73:642-9. https://doi.org/10.1016/j.sajb.2007.04.063.

7. Wilson D, Wilson A. Figs as a Global Spiritual and Material Resource for Humans. Hum Ecol. 2013;41:459-64. https//doi.org/10.1007/s10745-013-9582-z.

8. Sandeep AK, Dimple VT, Gat Y, Vikas K. Ficus religiosa: A wholesome medicinal tree. J Pharmacogn Phytochem. 2018;7:32-7.

9. Augustus GDPS, Seiler GJ. Ficus elastica - The Indian rubber tree - An underutilized promising multi-use species. Biomass Bioenergy Pergamon. 2011;35:3247-50. https://doi.org/10.1016/J.BIOMBIOE.2011.03.015.

10. Singh AK. Pharmacological Potentials of Ficus racemosa-A Review. Int. J. Pharm. Sci. Rev. Res. 2013.

11. Mordechai E, Kislev, Anat Hartmann OB-Y. Early Domesticated Fig in the Jordan Valley. Science (80-). $2006 ; 312$.

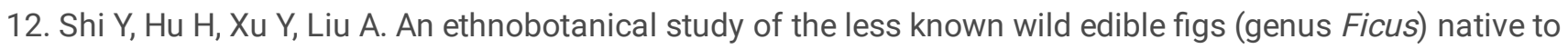
Xishuangbanna, Southwest China. J Ethnobiol Ethnomed. 2014;10:68. https://doi.org/10.1186/1746-4269-10-68.

13. https://doi.org/10.2307/23493222.

14. Khin S, Myat T. Some medicinal and useful plants, both indigenous and exotic, of Burma. Yangon: Ma Khin Khin Aye Publ House; 1970. pp. 12-3.

15. Ashin NB. Ashin Nargathein: Pone-pya-say-abidan (Illustrated dictionary of traditional Medicinal plants) (Myanmar version). Myanmar: Mingalar Press Yangon; 1973.

16. Lwin K, Lwin M. Medicinal Plant List of Myanmar. FAME Publ. House. 2015.

17. Shin T, Fujikawa K, Moe AZ, Uchiyama H. Traditional knowledge of wild edible plants with special emphasis on medicinal uses in Southern Shan State, Myanmar. J Ethnobiol Ethnomed. 2018;14:1-13. https://doi.org/10.1186/s13002-018-0248-1.

18. Whitney CW, Min VS, Giang LH, Can V, Van, Barber K, Lanh TT. Learning with elders: Human ecology and ethnobotany explorations in Northern and Central Vietnam. Hum Organ. 2016;75:71-86. https://doi.org/10.17730/0018-725975.1.71.

19. Hadden R. The Geology of Burma (Myanmar): An annotated Bibliography of Burma's Geology, Geography and Earth Science. Bibliogr. Burman Earth Sci. 2008.

20. Than AM, Harano T, Harano K, Myint AA, Ogino T, Okadaa S. High Incidence of 3-Thalassemia, Hemoglobin E, and Glucose-6-Phosphate Dehydrogenase Deficiency in Populations of Malaria-Endemic Southern Shan State, Myanmar. Int J Hematol. 2005;82:119-23. https://doi.org/10.1532/ijh97.05028.

21. UNDP M. THE STATE OF LOCAL GOVERNANCE: TRENDS IN SHAN. 2015.

Page 14/19 
22. Douglas G. Performing Ethnicity in Southern Shan State, Burma/Myanmar: The Ozi and Gong Traditions of the Myelat. Ethnomusicology. 2013;57:185-206.

23. Ministry of Labor I and P. The 2014 Myanmar Population and Housing Census, Shan State [Internet]. 2014. http://www.dop.gov.mm/en/state-region/shan.

24. Myint AA. Analysis of drivers of deforestation and forest degradation in Shan State and strategic options to address those. ICIMOD-GIZ REDD + Proj. 2015.

25. Nang AAC. PA-O COMMUNITY IN. THE SOUTHERN SHAN STATE (1886-1962). 26. Myanmar: Univ Mandalay; 2014.

26. Naderifar M, Goli H, Ghaljaie F. Snowball Sampling: A Purposeful Method of Sampling in Qualitative Research. STRIDES Dev Med Educ. 2017;14. https://doi.org/10.5812/sdme.67670.

27. Phillips 0 . Some quantitative methods for analyzing ethnobotanical knowledge. Selected Guidelines for Ethnobotanical Research: A field manual. Edited by M. Alexiades \& J.W. Sheldon. New York Bot. Gard. Press. Bronx, New York. 1996. p. 171-97.

28. Gaoue OG, Coe MA, Bond M, Hart G, Seyler BC, McMillen H. Theories and Major Hypotheses in Ethnobotany. Econ Bot. 2017;71:269-87. https:doi.org/10.1007/s12231-017-9389-8.

29. Chen SL, Yu H, Luo HM, Wu Q, Li CF, Steinmetz A. Conservation and sustainable use of medicinal plants: Problems, progress, and prospects. Chinese Med (United Kingdom). BioMed Central. 2016;11:1-10. https://doi.org/10.1186/s13020-016-0108-7.

30. Liu Y, Ahmed S, Liu B, Guo Z, Huang W, Wu X, et al. Ethnobotany of dye plants in Dong communities of China. J Ethnobiol Ethnomed. 2014;10. https://doi.org/10.1186/1746-4269-10-23.

31. WFO. World Flora Online. Published on the Internet; Accessed on: 09 May 2020 [Internet]. http://www.worldfloraonline.org.

32. Hoffman B, Gallaher T. Importance indices in ethnobotany. Ethnobot Res Appl. 2007;5:201-18. https://doi.org/10.17348/era.5.0.201-218.

33. Bhatia H, Sharma YP, Manhas RK. Traditionally used wild edible plants of district Udhampur, J\&K, India. J Ethnobiol Ethnomed. 2018;1:1-13. https://doi.org/10.1186/s13002-018-0272-1.

34. Phillips O, Gentry AH. THE USEFUL PLANTS OF TAMBOPATA. PERU " I. STATISTICAL HYPOTHESES TESTS WITH A NEW QUANTITATIVE TECHNIQUE 1. Econ Bot. 1993;47:15-32.

35. Phillips ND. YaRrr! The Pirate's Guide to R [Internet]. 2017. http://www.thepiratesguidetor.com.

36. Whitney C. “EthnobotanyR: Calculate Quantitative Ethnobotany Indices [R Package].” CRAN. 2019; https://github.com/CWWhitney/ethnobotanyR.

37. Brunson JC. Ggalluvial. Alluvial Plots in "Ggplot2" [Internet]. 2019. https://cran.r-project.org/package=ggalluvial.

38. Zhang L, Zhang Z, Wang X, Gao H, Tian H, Li H. Molecular Phylogeny of the Ficus auriculata Complex (Moraceae). Phytotaxa. 2018;362:39-54. https://doi.org/10.11646/phytotaxa.362.1.3.

39. Lim TK. Edible Medicinal and Non-Medicinal Plants: Volume 3, Fruits. Springer Sci Media VV. 2012. p. 358-95. https://doi.org/DOI 10.1007/978-94-007-2534-8\$455.

40. Chantarasuwan B, Welzen PC, Van. Which Species of Ficus subsection Urostigma in Thailand are used as Food, Ornamental Plants or Sacred Trees? Thail Nat Hist Museum J. 2012;6:145-51.

41. Devi M, Ningthoujam S, Ningombam D, Roy D. First Record of Ficus geniculata Kurz in Manipur, North East India. New York Sci J. 2015;8.

42. Verheij E, Coronel R. Plant Resources of South-East Asia-Edible fruits and nuts. version: 1.0. 1991.

43. Fern K, Fern A, Php RM-A http://tropical. theferns. info/. Useful Tropical Plants Database. 2014.

44. Berg CC, Corner EJH, Nooteboom HP. Moraceae (Ficus). Series I, Seed plants. In: Volume 17, Part 2: Moraceae (Ficus). Natl. Herb. Netherlands: Nationaal Herbarium Nederland; 2005. 
45. Hajar S, Aziz A, Zakaria Z, Mohammad ZR. Authenticity of Ficus hispida as a Local Traditional Product in the Lembah Lenggong World Heritage Site. SHS Web Conf. 2014;12. http://dx.doi.org/10.1051/shsconf/20141201098.

46. Roder W, Systems TG-A. 2003 U. Ficus auriculata - its relative importance in Bhutan, farmers' preference and fodder quality. Agrofor Syst. 2003;57:11-7.

47. Tiwaril MR, Khanall SK, Shrestha B, Jha RK. Nutritional variation of some fodder tree species found in different parts of Nepal. Nepal J Sci Technol. 2005;6:109-20.

48. Upreti S, Devkota NR. Ranking of Fodder Tree Species and Their Biomass Production in the hills and mountain of Nepal. J Agric For Univ. 2017;1:171-9.

49. Ying SS. The Tradition of Democracy in the Shan State. Cult Surviv Q Mag. 1989.

50. Shi Y, Mon AM, Fu Y, Zhang Y, Wang C, Yang X, et al. The genus Ficus (Moraceae) used in diet: Its plant diversity, distribution, traditional uses and ethnopharmacological importance. J Ethnopharmacol. 2018;226:185-96. https://doi.org/10.1016/j.jep.2018.07.027.

51. Dhami N. Ethnomedicinal Uses of Plants in Western Terai of Nepal: a Case Study of Dekhatbhuli Vdc of Kanchanpur District. Med plants Nepal An Anthol Contemp Res. 2008;164-76.

52. Kaur V, Kumar T, Upadhyaya K, Nagar S, Highway J-D, Campus B. AN OVERVIEW ON THE PHYTOMEDICINAL APPROACHES OF FICUS SEMICORDATA. World J Pharm Pharm Sci. 2018;5. https://doi.org/10.20959/wjpps201646397.

53. Yasmin Khan K, Ajab Khan M, Ahmad M, Mazari P, Hussain I, Ali B, et al. Ethno-medicinal Species of genus Ficus L. used to treat diabetes in Pakistan. J Appl Pharm Sci. 2011;1:209-11.

54. Khan MPZ, Ahmad M, Zafar M, Sultana S, Ali MI, Sun H. Ethnomedicinal uses of Edible Wild Fruits (EWFs) in Swat Valley, Northern Pakistan. J Ethnopharmacol Elsevier. 2015;173:191-203. http://dx.doi.org/10.1016/j.jep.2015.07.029.

55. Rajasab A, Isaq M. Documentation of folk knowledge on edible wild plants of North Karnataka. Indian J Tradit Knowl. 2004;03:419-29.

56. Gupta S, Acharya R. Ethnomedicinal claims of Ficus semicordata Buch.-Ham. ex Sm.: A review. Int J Green Pharm. 2018;12:206-13.

57. Mousa O, Vuorela P, Kiviranta J, Wahab SA, Hiltunen R, Vuorela H. Bioactivity of certain Egyptian Ficus species. J Ethnopharmacol. 1994;41:71-6. https://doi.org/10.1016/0378-8741(94)90060-4.

58. Ravangban P. Nat and Nat Kadaw: The Existence of the Local Cult in Myanmar Transition. Int Conf Burma/Myanmar Stud. 2015.

59. Volis S, Blecher M. Quasi. in situ: A bridge between ex situ and in situ conservation of plants. Biodivers Conserv. 2010;19:2441-54. https://www.doi.org/10.1007/s10531-010-9849-2.

60. Min YT. Conservation of two Ficus species with local community participation in Pindaya region, Southern Shan State, Myanmar. Ruffor Small Grants Found. 2009.

\section{Figures}




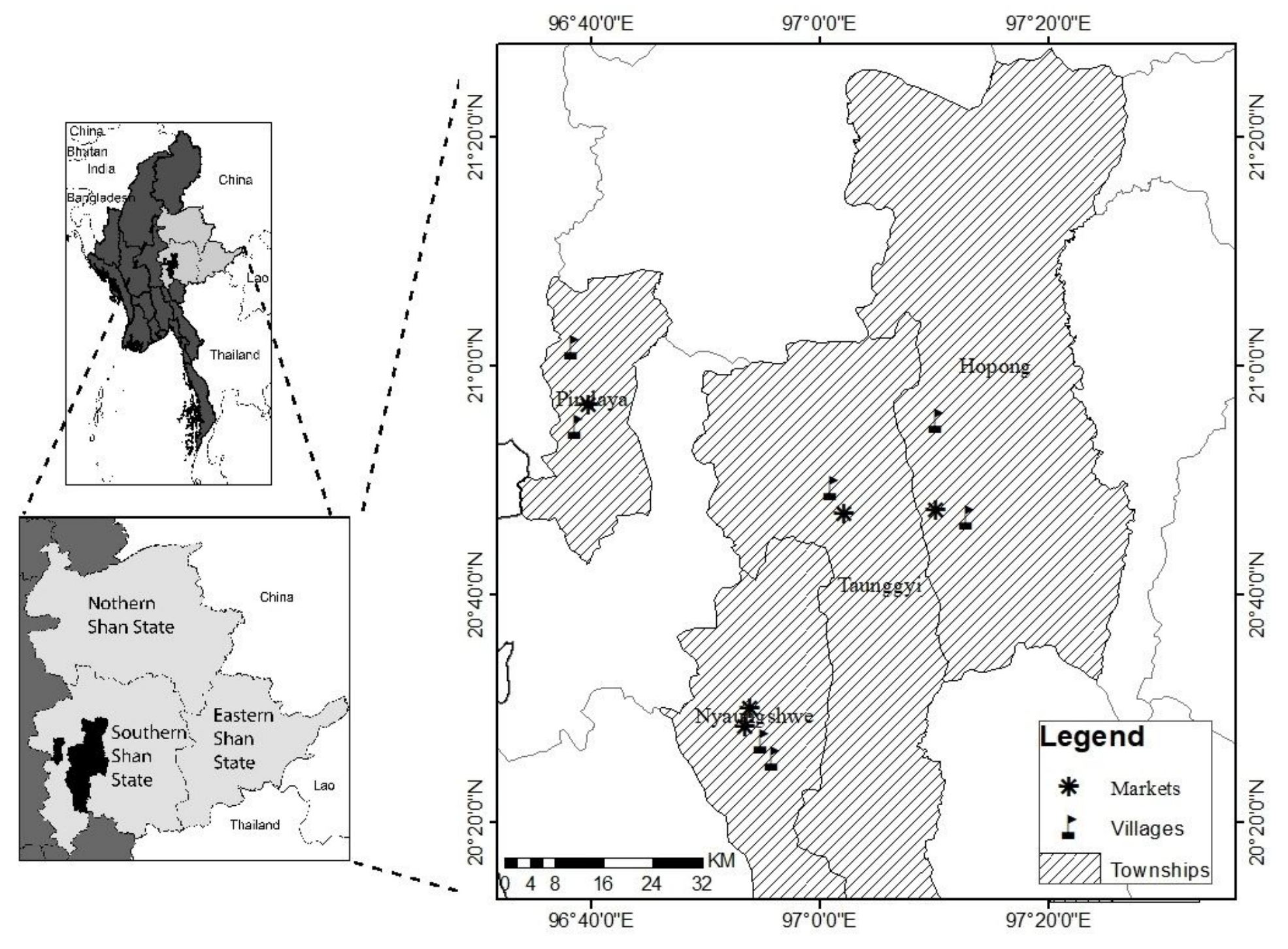

Figure 1

Study area including four townshipsin Southern Shan State, Myanmar. Fieldwork took place in five markets, five monasteries, and seven villages. 


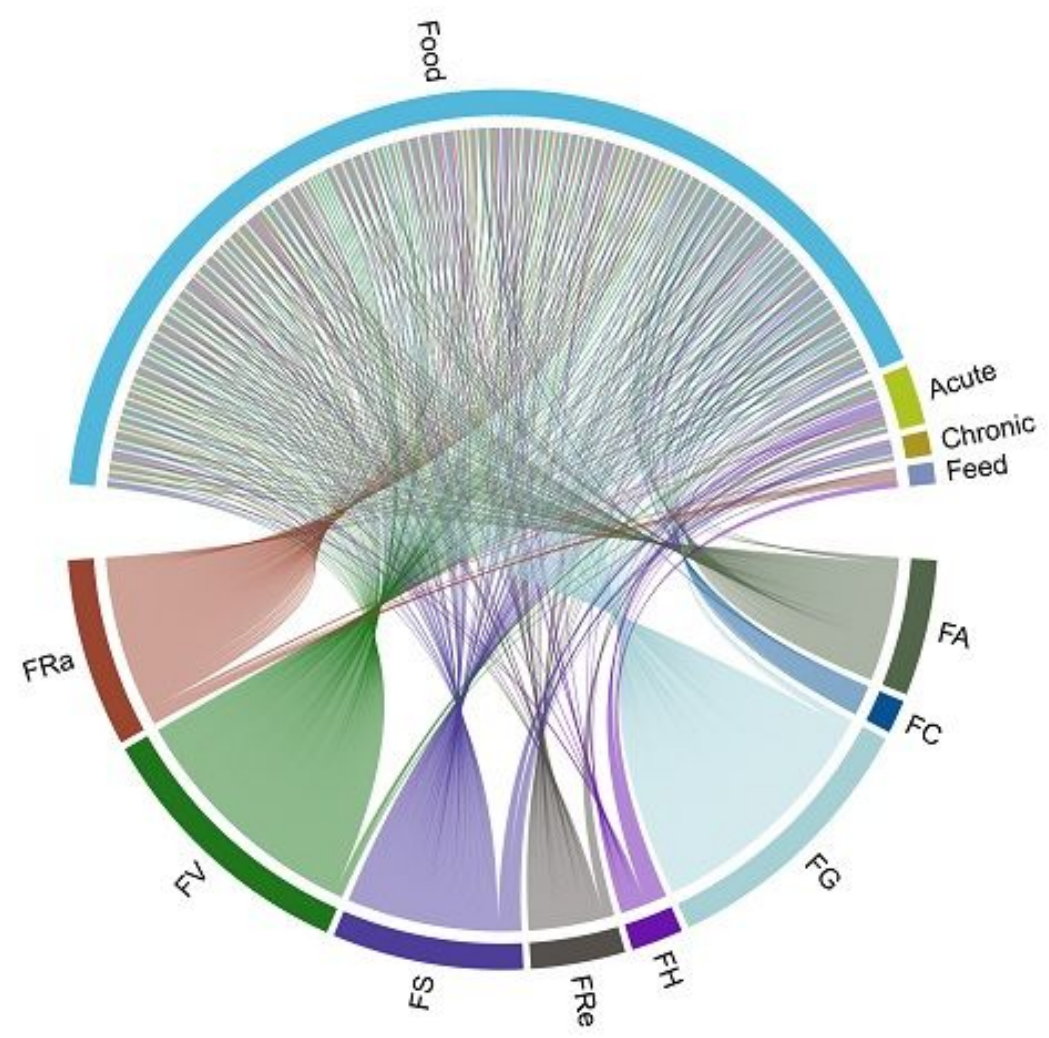

\section{Figure 2}

Chord diagram of the distribution of 923 use reports (UR) for eight fig species among 114 informants from five ethnic groups in four townships in Southern Shan State, Myanmar. The diagram shows the fourgeneralized used categories (top half) related to each of eightfigspecies (bottom half): FAF. auriculataLour. (F. oligodonMiq.),FCF. concinna(Miq.)Miq.,FGF. geniculataKurz, FHF. hispidaL.f., FRaF. racemosa L. (F. glomerataRoxb.), FReF.religiosaL., FSF. semicordataBuch.-Ham. ex Sm.,FVF. virensAivon.

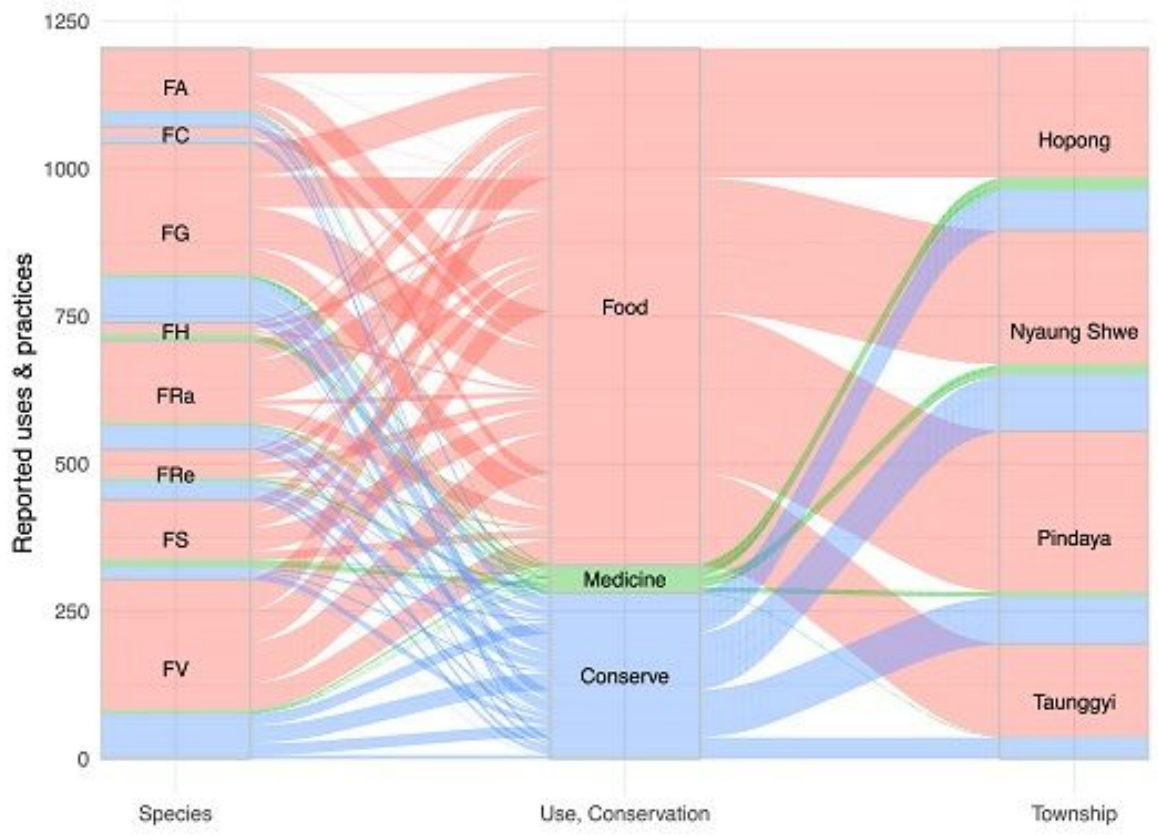

\section{Figure 3}


Alluvial plot of the 923 use reports (UR) for eight fig species and their usefulness as food, medicine and related conservation practices reported by 114 informants from five ethnic groupsinfour townships in Southern Shan State, Myanmar: FAF. auriculataLour. (F. oligodonMiq.),FCF. concinna(Miq.)Miq.,FGF. geniculataKurz, FHF. hispidaL.f., FRaF. racemosa L. (F. glomerataRoxb.), FReF. religiosaL., FSF. semicordataBuch.-Ham. ex Sm. (F. cuniaBuch.-Ham. ex Roxb.), FVF. virensAivon.

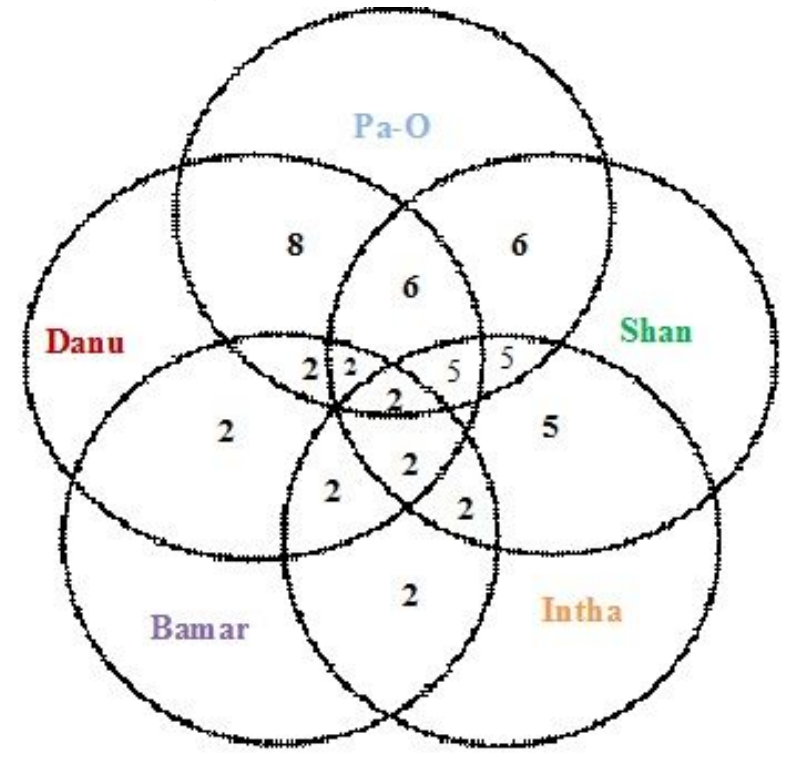

Figure 4

Venn diagram showing the overlap in usesfor eight figspeciesamong 114 informants from five ethnic groups in four townships in Southern Shan State, Myanmar. The overlap between circles represents the number of species that are commonly used between ethnic groups. No species were unique to a specific ethnic group. 